\title{
MOBILIZACE CHEMICKÝCH SLOŽEK STRUSKOVÉ DEPONIE V NÁRODNÍ PŘíRODNÍ REZERVACI RUDICKÉ PROPADÁNÍ
}

\author{
Mobilization of chemical compounds associated with slag dumps in the area of the Rudice \\ swallow hole National Nature Monument
}

\author{
Vít Baldík묘, Hana Krumlová2, David Buriánek', Eva Kryštofová', Jana Janderková', \\ Jan Sedláček', Roman Novotný', Martin Dostalík ${ }^{3}$ \\ ${ }^{1}$ Česká geologická služba, Leitnerova 22, 65869 Brno \\ 2 Ústav fyziky Země, Ústav fyziky Země PřF MU, Tvrdého 12, 60200 Brno \\ ${ }^{3}$ Česká geologická služba, Klárov 3, 11821 Praha 1
}

Key words: the Rudice swallow hole, speleothems, slag, heavy metals, $\mathrm{Zn}, \mathrm{Cd}, \mathrm{Cr}, \mathrm{Cu}$, sequential extraction

\begin{abstract}
The Rudice swallow hole (Rudické propadání) National Nature Monument is a locality affected by occasional mass movements and landslides. During exceptional rainfall events, the slag material from the slopes of a small valley called "Ve struskách" ("In the Slags") slides into an episodic stream, which enters the local karst system near the swallow hole of the Jedovnice Creek (Jedovnický potok). The slag was dumped in the locality in consequence of the past processing of iron ore in blast furnaces, which had been built near Jedovnice by the princely Salm family in the $19^{\text {th }}$ century. Even though the blast furnaces were closed down a hundred years ago, the slag components leaking into the Rudice stream sink cave system still demonstrably damage the speleothems. This was the major impulse for us to have a closer look at the geochemical properties of the slag.

The chemical composition was determined by silicate analyses carried out in the Institute of Geological Sciences at the Faculty of Sciences of the Masaryk University in Brno and in the ACME laboratories in Canada. The ACME laboratories determined heavy metal contents by atomic absorption spectroscopy (AAS) and by inductively coupled plasma mass spectrometry (ICP-MS). The petrographic characterization of the slag and its enclosures was conducted based on point analyses by a wavelength dispersive $X$ ray (WDX) electron microprobe. Predictions regarding the geochemical behavior of the slag components in an aqueous environment were made using the sequential extraction analysis (SEA) according to Tessier (1979).

We have found the expected spatial variability of the basic chemical composition of the slag dumps, as well as the presence of heavy metals (cadmium and especially zinc are present at high concentrations).

The slag material exhibits a glassy amorphous structure containing occasional mineral crystals, droplets of pure or oxidized iron and fragments of other materials (such as charcoal or blast furnace bricks). The ongoing weathering of the slag is accompanied by oxidation of crude iron and formation of limonite. Apart from that, the material is not subject to significant secondary transformations. The results of the sequential extraction analyses of slag and soil samples suggest that $C d$ and $Z n$ are chemically bound to the "carbonate fraction", which, in general, tends to dissolve under acidic conditions. Even though the environment of the carbonate rock cave systems is typically alkaline, there is a persisting risk of mobilization of heavy metals by acid soil solutions. From the environmental point of view, the slag deposition primarily represents a source of clastic material, which contaminates the cave system and damages speleothems by mechanical abrasion.
\end{abstract}

Úvod

Zájmové území náleží do Národní přírodní rezervace (NPR) Rudické propadání a reprezentuje typické hluboce zařizlé krasové slepé údolí s nejmohutnějším aktivním ponorným jícnem v České republice. Celý jeskynní systém Rudické propadání - Býčí skála protékaný Jedovnickým potokem a jeho př́toky má v současné době až po vývěr u Býčí skály téměr 13 kilometrů chodeb a komínů. Samotný bočnížlíbek „Ve struskách“, vyplněný struskou, představuje dnes již jen občasný pravostranný prrítok Jedovnického potoka $\mathrm{z}$ Rudické plošiny.

Zavážení žlíbku struskou bylo spojeno se zpracováním železné rudy v blízké Salmově Huti. Hrabě Salm ji založil v místech dnešní pily z důvodu obrovského polomu $\mathrm{v}$ roce 1746 . Hut zanikla koncem 19. století po ukončení těžby železných rud v okolí Rudice.

$\square$ vit.baldik@geology.cz

DOI: https://doi.org/10.5817/GVMS2018-1-2-108
Struska ze žlíbku v Rudickém propadání mechanicky degraduje krasovou výzdobu a usazuje se v jeskyních (Klepáč 2016). Akumulace strusky v krasových prostorách si už vyžádaly několik technických opatření, od výstavby dřevěných hrázek ve dně žlíbku (Srstková 2014) po odvoz materiálu před ústím propadání, která ale nebyla moc účinná.

\section{Geologická a hydrogeologická charakteristika studovaného území}

Geologické podloží studovaného území je budováno vilémovickými vápenci macošského souvrství devonského stáří. Z pohledu kvartérní geologie jsou zajímavé relikty pleistocenních písčitých štěrkủ po obou stranách Jedovnického potoka (Otava et al. 2013).

Z hydrogeologického hlediska leží NPP Rudické propadání v oblasti rozšiření krasovo-puklinového kolektoru vázáného na devonské vápence Moravského krasu. Devonské vápence na území Moravského krasu vytvářejí hydrogeologicky velmi proměnlivé prostředí 
se zastoupením různých typů porozity. I ve značně zkrasovělém prostředí se nacházejí rozsáhlé bloky téměř nepropustných, tektonicky nepostižených a nezkrasovělých hornin, které jsou omezeny dobře propustnými puklinovými systémy přecházejícími do otevřených puklin až kanálů a jeskynních systémů. Ponor Jedovnického potoka (vlastní Rudické propadání) představuje významný vstup vody do zvodnělého systému Moravského krasu. Bodové ponory jsou místa nejsnadnějšího vstupu kontaminantů do krasových zvodnělých systémů. Případné znečištění se může v krasovém podzemí rychle a nekontrolovatelně šírit díky rychlému proudění podzemní vody v otevřených kanálech s nízkou samočistící schopností a krasové hydrogeologické systémy jsou proto extrémně zranitelné antropogenními zásahy.

Žlíbkem „Ve struskách“, do něhož byla v minulosti struska zavážena, neprotéká žádný permanentní vodní tok. Drobný tok, který tudy v minulých letech protékal, vznikl antropogenně odtokem odpadních vod z čistírny odpadních vod (ČOV) Rudice. V současnosti je odtok napojen na ČOV Jedovnice a vodní tok směřující $\mathrm{k}$ Rudickému propadání je aktivní pouze za mimořádných srážkových událostí, kdy odvádí vodu z okolních pozemků, případně přetok z ČOV Rudice. V nekrasovém prostředí by dno žlíbku představovalo lokální drenážní bázi, pravděpodobně s vývěry nebo průsaky podzemní vody, at už stálými nebo občasnými. Vzhledem $\mathrm{k}$ pozici na krasových vápencích a $\mathrm{k}$ blízkosti bodového ponoru, na kterém povrchová voda při vstupu do jeskynních systémů překonává převýšení kolem 90 m, mưže však drenážní báze být zaklesnuta v podstatně větší hloubce, než je dno žlíbku. Erozní tvary ve dně žlíbku a přemístěné akumulace strusky svědčí o tom, že žlíbek je občasně za vysokých srážkových úhrnů protékán vodním tokem, který eroduje materiál depozice a transportuje ho směrem k soutoku s Jedovnickým potokem a ponorem dále do podzemí. Materiál ležící ve žlíbku současně interaguje s kyselými půdními roztoky a pomalu zvětrává.

\section{Metodika}

$\mathrm{V}$ rámci geochemického výzkumu struskové deponie byly provedeny následující práce: (1) odběr pěti směsných vzorků do hloubky jednoho metru ze struskové deponie (viz obr. 1), (2) prŕíprava vzorků pro analýzy (sušení, drcení na jemnost 0,03-0,80 mm, homogenizace), (3) komplexní charakteristika půd na lokalitě, (4) petrografická charakteristika strusky a součástek v ní obsažených bodovými analýzami na mikrosondě Cameca SX-100 [Laboratoř elektronové mikroskopie a mikroanalýzy - Ústav geologických věd Př́rodovědecké fakulty Masarykovy univerzity (dále ÚGV PřF MU) a Česká geologická služba (dále ČGS)], (5) silikátové analýzy (ƯGV PřF MU v Brně a laboratoře ACME v Kanadě + obsahy těžkých kovů metodou AAS a ICP-MS tamtéž), (6) sekvenční extrakční analýzy (SEA) dle Tessiera (1979) zaměřené na uvolňování těžkých kovů obsažených ve vzorcích (ÚGV PřF MU).
SEA podle Tessiera (1979) rozlišuje v pěti krocích následující frakce kovů, které jsou postupně louženy ze stejného vzorku různými chemickými činidly:

1. slabě sorpčně vázané na jílové minerály; snadno vyměnitelné a rychle reagují na změnu $\mathrm{pH}$ a složení roztoku,

2. vázané v karbonátech; reagují především na změnu $\mathrm{pH}$ (uvolňování v kyselém prostředí),

3. vázané na hydrooxidy železa a manganu; reagují na změnu $\mathrm{pH}$ a oxidačně-redukčního potenciálu (Eh). Zvýšení Eh (tj. směrem k oxidačním podmínkám) vede k oxidaci dvojmocných iontů Fe a Mn na trojmocné, které se při zvýšení pH srážejí v hydrooxidech,

4. vázané na organickou hmotu; uvolňují se až při rozkladu organické hmoty (především při oxidaci),

5. pevně vázané v minerálech; jsou vázány stabilně a transportovány především mechanicky.

Výsledky chemických analýz byly srovnány s limitními hodnotami níže uvedených metodických pokynů a doporučení, která jsou obvykle aplikována při hodnocení kontaminací horninového prostředí a půd rizikovými elementy. Zejména jsme se opírali o stále platný metodický pokyn MŽP z roku 1996 (Metodický pokyn MŽP ČR „Kritéria znečištění zemin a podzemní vody.“, Praha 1996). Užívá kategorie A (mezní hodnoty), B (limit kdy je nutno uvažovat o sanaci) a C (limit pro maximálně př́ípustné znečištění obytné zástavby). Podobné hodnoty uvádí i slovenský normativ z roku 1994 (Rozhodnutie MP

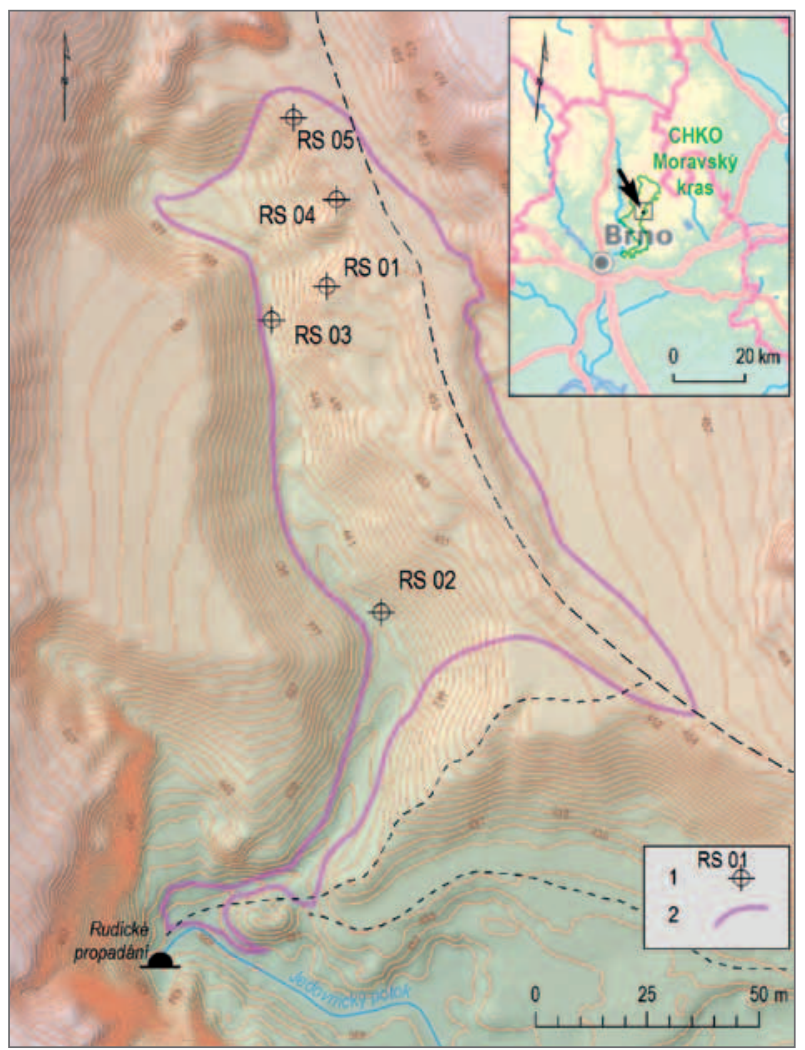

Obr. 1: Rozmístění sond pro odběr vzorků strusky v zájmovém území. 1 - odběrové body; 2 - oblast struskové depozice.

Fig. 1: Location of slag sampling sites in the studied area. 1 - sampling points; 2 - area of slag deposition. 
SR o najvyšších prípustných hodnotách škodlivých látok v pôde a o určení organizácií oprávnených zistovat’ skutočné hodnoty týchto látok č. 531/1994 - 540, Bratislava 1994). Na základě geochemických vlastností přítomných těžkých kovů, výsledků SEA a geochemických podmínek v oblasti jsme vyhodnotili míru nebezpečnosti struskové deponie nad Rudickým propadáním pro životní prostředí z geochemického hlediska.

\section{Charakteristika odebraných vzorků}

Pro studium byly odebrány vzorky z různých částí struskové haldy (obr. 1), které reprezentují odlišné typy materiálu splavovaného do jeskynních systémů.

Odebrané vzorky RS 01-RS 05 vykazují následující makroskopické charakteristiky:

RS 01: Prakticky čistá struska, hrubozrnný ostrohranný materiál černé barvy s výrazným skelným leskem. Místy rezivé skvrny. Velikost jednotlivých úlomků se pohybuje od 2 do $50 \mathrm{~mm}$, občas se vyskytují úlomky větší (cca $70 \mathrm{~mm}$ ). Příměs půdy je zanedbatelná, příměs písku a prachu. Obsah hrubého skeletu nad $90 \%$.

RS 02: Zahliněná struska. Jednotlivé úlomky strusky obaleny hlinitým až jílovitohlinitým materiálem s příměsí písku, tmavě olivově hnědé barvy. Velikost jednotlivých úlomků se pohybuje od 2 do $50 \mathrm{~mm}$, občas se vyskytují úlomky větší (cca $70 \mathrm{~mm}$ ), obsah hrubého skeletu od 80 do $90 \%$.

RS 03: Prakticky čistá struska, hrubozrnný ostrohranný materiál černé barvy s výrazným skelným leskem. Místy rezivé skvrny. Velikost jednotlivých úlomků se pohybuje od 2 do $50 \mathrm{~mm}$, občas se vyskytují úlomky větší (cca $70 \mathrm{~mm}$ ). Příměs půdy je zanedbatelná, příměs písku a prachu. Obsah hrubého skeletu nad $90 \%$.

RS 04: Směs strusky a půdy s příměsí popela. Velikost jednotlivých úlomků se pohybuje od 2 do $50 \mathrm{~mm}$, občas se vyskytují úlomky větší (cca $70 \mathrm{~mm}$ ). Obsah hrubého skeletu přibližně $60 \%$. Pưda hlinitopísčitá s příměsí prachovité frakce, hnědočerná.

RS 05: Směs strusky a půdy s prríměsí popela. Velikost jednotlivých úlomků se pohybuje od 2 do $50 \mathrm{~mm}$, občas se vyskytují úlomky větší (cca $70 \mathrm{~mm}$ ). Půda hlinitopísčitá s prríměsí prachovité frakce, hnědočerná. Příměs prachu je vyšší než u RS 04.

\section{Výsledky a jejich diskuze}

Půdy odrážejí především substrátovou, reliéfovou a vegetační rozmanitost zájmového území a způsob jeho využívání, včetně změn. Žlíbek je poměrně hluboko zaříznut $\mathrm{v}$ kvartérních hlinitých a hlinitokamenitých sedimentech. Jeho dno tvoří splachové hlinité sedimenty. Levobřežní i pravobřežní svahy jsou zalesněny. Pravobřežní svahy jsou strmější a v místech, kde vystupují k povrchu vápence, je pokrývají rendziny. Rendziny jsou půdy s nasyceným sorpčním komplexem a stabilizovanými formami humusu. Jde o kypré půdy dobře propustné pro vodu. Část zájmového území je překryta hlinitými až hlinitokamenitými sedimenty, ze kterých se vyvinuly kambizemě. Půdy levobřežních svahů žlíbku na struskách lze klasifikovat jako antropozemě. Polohy, které jsou
Tab. 1: Silikátové analýzy vzorků strusky RS 01 až RS 05. Tab. 1: Silicate analyses of the slag samples RS 01 to RS 05.

\begin{tabular}{|c|c|c|c|c|c|}
\hline $\mathbf{m} \%$ & RS 01 & RS 02 & RS 03 & RS 04 & RS 05 \\
\hline $\mathbf{- H}_{\mathbf{2}} \mathbf{O}$ & 0,37 & 0,75 & 0,25 & 1,14 & 0,81 \\
\hline$+\mathbf{H}_{\mathbf{2}} \mathbf{O}$ & 0,78 & 2,36 & 0,96 & 3,55 & 3,22 \\
\hline $\mathbf{S i O}_{\mathbf{2}}$ & 45,46 & 49,95 & 45,9 & 52,66 & 60,16 \\
\hline $\mathbf{T i O}_{\mathbf{2}}$ & 0,55 & 0,62 & 0,59 & 0,53 & 0,57 \\
\hline $\mathbf{A l}_{\mathbf{2}} \mathbf{O}_{\mathbf{3}}$ & 12,44 & 13,5 & 12,54 & 9,39 & 9,8 \\
\hline $\mathbf{F e}_{\mathbf{2}} \mathbf{O}_{\mathbf{3}}$ & 1,53 & 2,14 & 0,61 & 6,64 & 5,87 \\
\hline $\mathbf{F e O}$ & 2,32 & 2,06 & 2,48 & 5,38 & 4,17 \\
\hline $\mathbf{M n O}$ & 0,76 & 0,72 & 0,9 & 0,39 & 0,32 \\
\hline $\mathbf{C a O}$ & 31,81 & 23,22 & 31,38 & 12,49 & 11,43 \\
\hline $\mathbf{M g O}$ & 0,21 & 0,25 & 0,23 & 0,17 & 0,18 \\
\hline $\mathbf{K}_{2} \mathbf{O}$ & 1,91 & 2,19 & 2,12 & 1,59 & 1,74 \\
\hline $\mathbf{N a} \mathbf{O}_{\mathbf{2}}$ & 0,26 & 0,38 & 0,26 & 0,58 & 0,1 \\
\hline $\mathbf{C O}$ & 0,17 & 0,52 & 0,3 & 0,95 & 0,41 \\
\hline $\mathbf{P}_{\mathbf{2}} \mathbf{O}_{\mathbf{5}}$ & 0,05 & 0,19 & 0,06 & 0,33 & 0,23 \\
\hline $\mathbf{Z n O}$ & - & - & - & 1,6 & - \\
\hline $\mathbf{T O T} / \mathbf{C}$ & 1,73 & 0,97 & 0,81 & 2,42 & 0,84 \\
\hline $\mathbf{T O T} / \mathbf{S}$ & 0,09 & 0,09 & 0,1 & 0,1 & 0,07 \\
\hline $\mathbf{s u m a}$ & 100,35 & 99,82 & 99,39 & 99,81 & 99,85 \\
\hline
\end{tabular}

tvořené prakticky čistou struskou pak jako antropické substráty (Němeček et al. 2011). Půdy v zájmovém území i v jeho bezprostředním okolí i samotné antropogenní vrstvy strusky lze na základě jejich infiltrační schopnosti zařadit $\mathrm{z}$ větší část do hydrologických skupin půd $\mathrm{A}$ a $\mathrm{B}$, tj. mezi půdy s vysokou až střední rychlostí infiltrace i při úplném nasycení, dobře až středně dobře odvodněné.

Kusový struskový materiál má sklovitou amorfní strukturu a vedle toho obsahuje krystaly minerálů, kapky surového nebo zoxidovaného železa a cizorodé fragmenty (například úlomky dřevěného uhlí či vyzdívky vysoké pece). Při zvětrávaní strusky dochází k oxidaci surového železa a vzniku limonitu. Během pedogenetických procesů dochází u strusky $\mathrm{k}$ devitrifikaci a to především na povrchu a podél trhlin. Tento proces je však velmi pomalý a tlouštłka alterované části strusky nepřesahuje 1-2 mm. Klasty strusky tak zůstávají ostrohranné a pevné. Na druhou stranu velmi drobné úlomky strusky (pod $1 \mathrm{~mm}$ ) jsou devitrifikací postiženy významně a mohou se z nich uvolňovat do okolí polutanty.

Výsledky pilotních analýz zpracovaných laboratoří na ÚGV PřF MU uvádí tabulka 1. Jde vesměs o průměrné hodnoty ze dvou exemplářu téhož vzorku (pro kontrolu správnosti př́ípravy vzorku i analýz samotných; označeny jako a, b - viz obr. 2-5). Analýzy těchto vzorků na obsahy vybraných toxických kovů jsou uvedeny v tabulce 2 (spolu s mezemi detekce). Kvalita výsledků je navíc ověřena analýzami zadanými následně do referenčních laboratoří ve Vancouveru v Kanadě. Ani v jednom vzorku nebyl zjištěn As v obsazích nad mezí detekce. Nejvyšší obsahy organického uhlíku obsahují vzorky RS 04 a RS 01 odebrané ze srázu poblíž cesty. Významně zvýšené jsou koncentrace $\mathrm{Cd}(140 \mathrm{ppm})$ a zejména $\mathrm{Zn}$ (extrémně vysoké hodnoty přes $15900 \mathrm{ppm}$ ) zjištěné pro vzorek RS 04. Tyto skutečnosti vyžadují další šetření a ověřující odběrové práce. Pro Cr nemáme potřebné srovnávací mezní hodnoty, přesto jsou u všech vzorků překročeny průměrné koncentrace, které pro zemskou kůru i pro půdy uvádí 


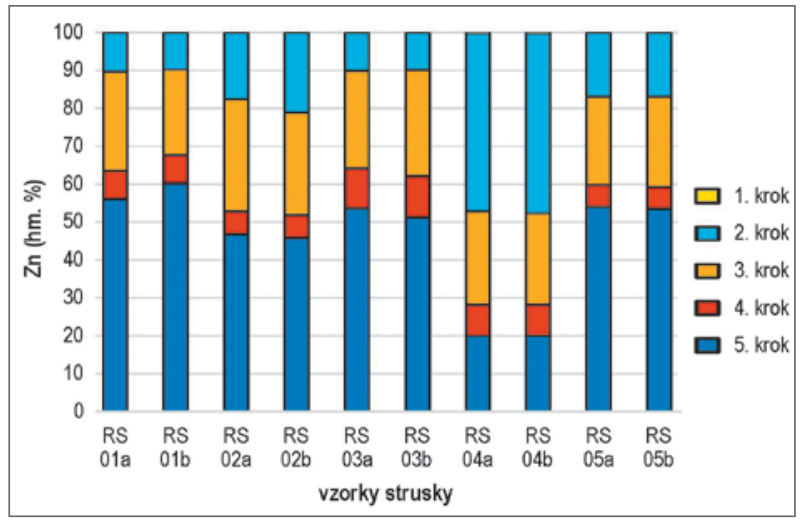

Obr. 2: Relativní zastoupení Zn v jednotlivých frakcích SEA. Fig. 2: Relative distribution of $\mathrm{Zn}$ among the SEA fractions.

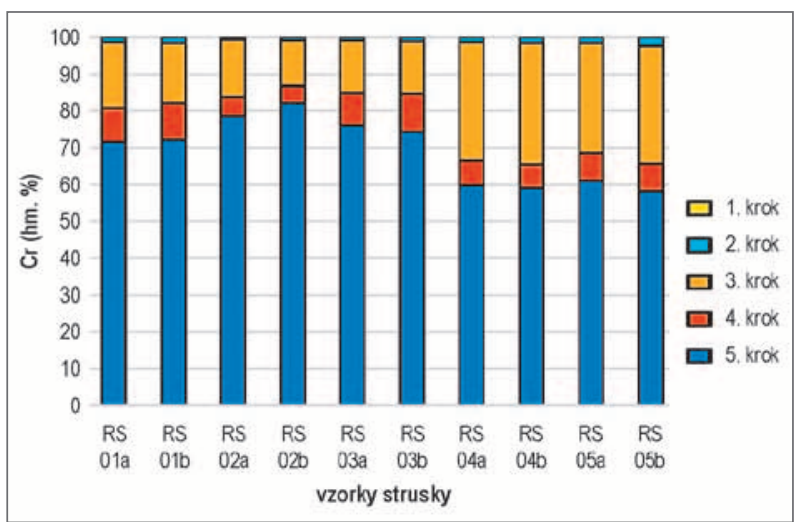

Obr. 3: Relativní zastoupení Cr v jednotlivých frakcích SEA Fig. 3: Relative distribution of $\mathrm{Cr}$ among the SEA fractions.

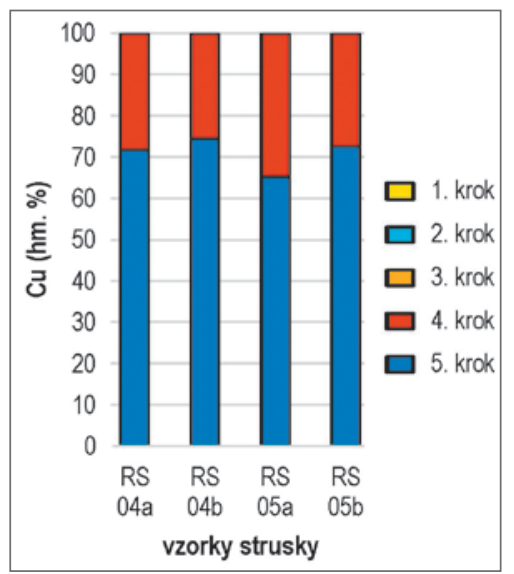

Obr. 4: Relativní zastoupení $\mathrm{Cu} v$ jednotlivých frakcích SEA u vzorků RS 04 a RS 05.

Fig. 4: Relative distribution of $\mathrm{Cu}$ among the SEA fractions in the slag samples RS 04 and RS 05.

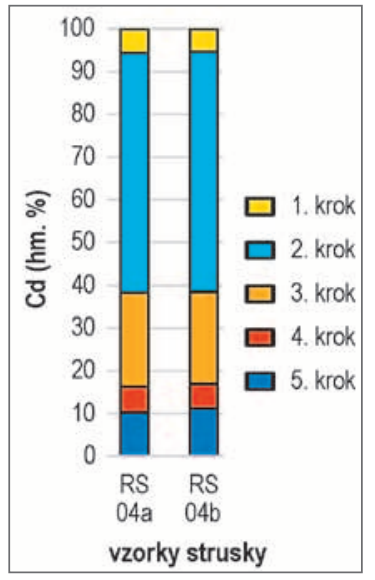

Obr. 5: Relativní zastoupen Cd v jednotlivých frakcích SEA u vzorku RS 04 .

Fig. 5: Relative distribution of Cd among the SEA fractions in the slag sample RS 04.
Čurlík (2011). Koncentrace Cu je nad mezí detekce pouze u vzorků RS 04 a RS 05.

Na základě chemické analýzy (viz tab. 2) byla pomocí SEA zkoumána mobilita Zn (obr. 2) a Cr (obr. 3) na všech vzorcích, Cu na vzorcích RS 04 a RS 05 (obr. 4) a Cd na vzorku RS 04 (obr. 5).

Zn a Cd se z geochemického hlediska chovají podobně, což potvrzuje i stejný „vzor“ zastoupení kovů v jednotlivých frakcích, jak vidíme u vzorku RS 04 na obrázcích 2 a 5 .

Sledované těžké kovy nejsou ve struskách snadno vyměnitelné. První frakce kovů dle SEA v odebraných vzorcích bud' zcela chybí ( $\mathrm{Cr}$ a $\mathrm{Cu}$, viz obr. 3 a 4), nebo v případě Cd ve vzorku RS 04 tvoří jen několik málo procent $(5,5 \%$, viz obr. 5$)$ či desetin procenta $v$ prrípadě Zn (0,2 \%, viz obr. 2$)$ ve vzorku RS 04 z celkového obsahu daného kovu.

Nejvíce Zn (47\%) a Cd (56\%) ve vzorku RS 04 je zastoupeno ve druhé frakci SEA, tj. vázáno na karbonáty. To znamená, že dostane-li se vzorek s takto vázanými kovy do kyselého prostředí, kde se začnou rozpouštět karbonáty, tak spolu s nimi se do prostředí uvolní i vázané těžké kovy.

Ve třetí frakci vzorku RS 04, tj. v hydrooxidech Fe a Mn je vázáno $24 \% \mathrm{Zn}$ a $22 \% \mathrm{Cd}$. Hydrooxidy železa $\left(\mathrm{Fe}_{2} \mathrm{O}_{3} \cdot \mathrm{nH}_{2} \mathrm{O}\right)$ jsou stabilní v poměrně širokém rozmezí $\mathrm{pH}$ blízko nulového oxidačně-redukčního potenciálu. V kyselém prostředí se rozpouští a tvoří samostatné ionty a komplexy $\mathrm{v}$ roztoku. $\mathrm{V}$ podmínkách stability hydrooxidů Fe by měly být stabilně vázány i těžké kovy v nich přítomné.

V ostatních vzorcích vyjma vzorku RS 04 je $\mathrm{Zn}$ zastoupen $\mathrm{v}$ jednotlivých frakcích velmi podobně (viz obr. 2). Suma kovu v 1., 2. a 3. frakci SEA nepřevyšuje $50 \%$. Čtvrtá frakce kovu vázaná na organickou hmotu dosahuje max. $11 \%$ u vzorku RS 03. Poměrně malá část $\mathrm{Zn}$ a Cd je opravdu pevně vázána v materiálu vzorku RS 04. Naopak u ostatních vzorků je více než polovina $Z n$ vázána $\mathrm{v}$ materiálu struskové deponie pevně.

U Cu a Cr je také nadpoloviční množství z celkového obsahu kovu vždy vázáno na poslední frakci SEA - tj. pevně ve „struktuře“ vzorku. Měd” je kromě toho ještě významně zastoupena ve frakci vázané na organickou hmotu (viz obr. 4 , od 25 do $35 \%$ ) a Cr na hydrooxidy Fe a Mn (viz obr. 3, od 12 do $33 \%$ ). Z hlediska nebezpečnosti uvolnění ze struskového materiálu je výsledný „vzor“ rozložení frakcí SEA u Cu a Cr pro životní prostředí př́íznivý.

Pro př́padnou mobilizaci a vyplavování chemických látek vázaných ve strusce má význam doba zdržení vody ve struskové depozici, inertnost materiálu a chemické složení půdních roztoků a srážkové vody, která tělesem strusky protéká, zejména hodnota $\mathrm{pH}$. Doba zdržení vody $\mathrm{v}$ horninovém prostředí ( $\mathrm{v}$ tomto prrípadě $\mathrm{v}$ akumulaci strusky) je závislá na hydraulické vodivosti materiálu, na morfologické pozici a na výškovém gradientu. Charakter popsaného materiálu ve struskové depozici naznačuje na silně až velmi silně propustné prostředí v závislosti na obsahu hlíny, písku, popela a prrípadných dalších příměsí. Po celou dobu terénních prací na lokalitě v roce 2017 bylo dno žlíbku suché bez jakýchkoli vývěrů nebo 
průsaků pod tělesem strusky. Nebylo proto možné odebrat vzorky vody ke zjištění přítomnosti kovů případně dalších sloučenin.

V jeskynních systémech jako takových nelze kyselé podmínky očekávat, o čemž svědčí i hodnoty $\mathrm{pH}$ v rozmezí 6,73-7,10 zjištěné na vývěrech Jedovnického potoka v Josefovském údolí. Rovněž hodnoty $\mathrm{pH}$ Jedovnického potoka nad Rudickým propadáním se pohybují okolo 6,5-7,0. Nicméně v místě depozice struskový materiál interaguje jak se srážkovými vodami, tak s kyselými půdními roztoky a uvolňování části kovů vázaných na karbonáty nelze vyloučit. Předpokládáme však, že výsledné koncentrace kovů v krasových vodách nepřesáhnou povolené limity. Nebezpečný tak zůstává hlavně klastický materiál, který zatěžuje jeskynní prostředí.

\section{Závěr}

Struska je významným antropogenním činitelem, který ovlivňuje celý jeskynní systém Rudické propadání - Býčí skála. Větší klasty strusky jsou poměrně odolné vůči zvětrávání a zachovávají si ostré lomové hrany. Srážková voda, která na depozici dopadne, zřejmě velmi rychle infiltruje do strusky, interaguje s půdními roztoky, díky velkému spádu rychle protéká ke dnu žlíbku a dále ve směru jeho osy, př́ípadně do hlubších partií krasově-puklinového horninového prostředí. K dočasnému zdržení infiltrované srážkové vody v materiálu depozice může dojít při jeho bázi zejména u dna žlíbku.

Z výsledků geochemických analýz vyplývá, že chemické složení strusky je velmi pestré. Liší se jak v obsazích základních oxidů $\left(\mathrm{CaO}, \mathrm{Al}_{2} \mathrm{O}_{3} \ldots\right)$, tak i v koncentracích těžkých kovů. Část kovů (Cd, Zn) je částečně vázána na „karbonátovou frakci“ SEA. Ačkoli v krasovém prostředí nízké $\mathrm{pH}$ nepředpokládáme, tak mobilizaci kovů ve strusce ani jejich další transport horninovým prostředím, nelze vyloučit. Struskový materiál je „in situ“ vystaven účinkům zvětrávání za působení kyselých půdních roztoků. Během deštů tak může docházet kromě mobilizace pevného materiálu i k rozpouštění/ vyluhování a transportu kovů. Nepředpokládáme však, že dosažené koncentrace kovů v krasových vodách budou rizikové. Z environmentálního hlediska tedy představuje strusková deponie především zdroj klastického materiálu, který znečištuje jeskynní systém a ohrožuje speleotémy mechanickou abrazí.

\section{Poděkování}

Autoři děkují editorovi doc. Ing. Jiřimu Faimonovi a recenzentům Mgr. Pavlu Pracnému, Ph.D. a RNDr. Jiř́mu Otavovi, CSc. za kritické pročtení rukopisu. Práce byla vypracována s finanční podporou projektu OG MŽP a $\check{C} G S 386700$.

Literatura

Čurlík, J. (2011). Potenciálne toxické stopové prvky a ich distribúcia v pôdach Slovenska. Prírodovedecká fakulta Univerzity Komenského, Bratislava, $462 \mathrm{~s}$.

Klepáč, V. (2016). Krápníky v Moravském krasu ohrožuje struska. - Právo, 9. srpna, 2016.

Němeček, J., Mühlhanselová, M., Macků, J., Vokoun, J., Vavříček, D., Novák, P. (2011). Taxonomický klasifikační systém půd České republiky. 2. upravené vydání, Česká zemědělská univerzita, Praha, $94 \mathrm{~s}$.

Otava, J., Balák, I., Baldík, V., Bubík, M., Buriánek, D., Čáp, P., Černý, J., Franců, J., Fürychová, P., Gilíková, H., Havlín, A., Hladil, J., Janderková, J., Kociánová, L., Kolejka, V., Konečný, F., Kryštofová, E., Kumpan, T., Melichar, R., Müller, P., Paleček, M., Pecina, V., Pecka, T., Sedláček, J., Sedláčková, I., Šrámek, J., Tomanová Petrová, P., Večeřa, J., Vít, J. (2013). Vysvětlivky k Základní geologické mapě České republiky 1:25 000, list 24-411 Jedovnice. - 298 s. MS, Archív České geologické služby, Brno.

Srstková, P. (2014). Struska přestane ničit propadání. - Blanenský deník, 22. srpna, 2014.

Tessier, A., Campbell, P. G. C., Bisson, M. (1979). Sequential extraction procedure for the speciation of particulate trace metals. - Analytical Chemistry, 51, 844-851.

Editor: Jiří Faimon

Doporučená citace článku: Baldík, V., Krumlová, H., Buriánek, D., Kryštofová, E., Janderková, J., Sedláček, J., Novotný, R., Dostalík, M. (2018). Mobilizace chemických složek struskové deponie v Národní př́rodní rezervaci Rudické propadání. - Geologické výzkumy na Moravě a ve Slezsku, 25, 1-2, 108-112. 